\title{
The Role of Deep Geofluids in the Enrichment of Sedimentary Organic Matter: A Case Study of the Late Ordovician-Early Silurian in the Upper Yangtze Region and Early Cambrian in the Lower Yangtze Region, South China
}

\author{
Kun Zhang $\mathbb{D}^{1,2,3}$ Jun Peng ${ }^{1},{ }^{1}$ Weiwei Liu, ${ }^{4}$ Bin Li, ${ }^{1,5}$ Qingsong Xia, ${ }^{1}$ Sihong Cheng, ${ }^{4,6,7}$ \\ Yiming Yang, ${ }^{1}$ Yao Zeng, ${ }^{1}$ Ming Wen, ${ }^{8,9}$ Dongmei Liu, ${ }^{10}$ Yizhou Huang, ${ }^{11}$ Li Zhong, \\ Pei Liu, ${ }^{1}$ and Xiaojun Jiang ${ }^{1}$ \\ ${ }^{1}$ School of Geoscience and Technology, Southwest Petroleum University, Chengdu 610500, China \\ ${ }^{2}$ State Key Laboratory of Oil and Gas Reservoir Geology and Exploitation, Southwest Petroleum University, Chengdu 610500, China \\ ${ }^{3}$ Key Laboratory of Tectonics and Petroleum Resources, China University of Geosciences, Ministry of Education, \\ Wuhan 430074, China \\ ${ }^{4}$ Jiangxi Provincial Shale Gas Investment Company, Ltd., Nanchang 330000, China \\ ${ }^{5}$ State Key Laboratory of Shale Oil and Gas Enrichment Mechanisms and Effective Development, SINOPEC, Wuxi 214162, China \\ ${ }^{6}$ Institute of Sedimentary Geology, Chengdu University of Technology, Chengdu 610059, China \\ ${ }^{7}$ State Key Laboratory of Oil and Gas Reservoir Geology and Exploitation, Chengdu University of Technology, \\ Chengdu 610059, China \\ ${ }^{8}$ State Key Laboratory of Petroleum Resources and Prospecting, China University of Petroleum, Beijing 102249, China \\ ${ }^{9}$ Unconventional Natural Gas Institute, China University of Petroleum, Beijing 102249, China \\ ${ }^{10}$ School of Materials Science and Engineering, Jiamusi University, Jiamusi 154007, China \\ ${ }^{11}$ Organic Geochemistry Unit, School of Chemistry, University of Bristol, Cantock's Close, Bristol BS8 1TS, UK
}

Correspondence should be addressed to Jun Peng; pengjun@swpu.edu.cn

Received 25 September 2020; Revised 1 November 2020; Accepted 13 November 2020; Published 18 December 2020

Academic Editor: Liu Quanyou

Copyright (c) 2020 Kun Zhang et al. This is an open access article distributed under the Creative Commons Attribution License, which permits unrestricted use, distribution, and reproduction in any medium, provided the original work is properly cited.

Organic matter is the material basis for shales to generate hydrocarbon, as well as the main reservoir space and seepage channel for shale gas. When the thermal evolution degree is consistent, the organic carbon content in present shales is subject to the abundance of primitive sedimentary organic matter. Deep geofluids significantly influence the sedimentary organic matter's enrichment, but the mechanism remains unclear. This paper is aimed at determining how hydrothermal and volcanic activities affected the enrichment of sedimentary organic matter by studying lower Cambrian shales in the lower Yangtze region and upper Ordovician-lower Silurian shales. Oxidation-reduction and biological productivity are used as indicators in the study. The result shows that hydrothermal or volcanic activities affected the enrichment of sedimentary organic matter by influencing climate changes and the nutrients' sources on the waterbody's surface and reducing water at the bottom. In the lower Cambrian shales of the Wangyinpu Formation in the lower Yangtze region, hydrothermal origin caused excess silicon. During the sedimentary period of the lower and middle-upper Wangyinpu Formation, vigorous hydrothermal activities increased the biological productivity on the waterbody's surface and intensified the reducibility at the bottom of the waterbody, which enabled the rich sedimentary organic matter to be well preserved. During the sedimentary period of the lower upper Ordovician Wufeng Formation and the lower Silurian Longmaxi Formation in the upper Yangtze region, frequent volcanic activities caused high biological productivity on the waterbody surface and strong reducibility at the bottom of the waterbody. As a result, the abundant organic matter deposited from the water surface can be well preserved. During the sedimentary period of the upper Longmaxi Formation, volcanic activities died down gradually then disappeared, causing the biological productivity on the water surface to decrease. Besides, the small amount of organic matter deposited from the water surface was destroyed due to oxidation. 


\section{Introduction}

Since 2000, progresses made in exploration concepts and technology have made shale gas prospection considerable success in North America [1-3]. China is also abundant in shale gas resources. Commercial exploitation has been approved in Weiyuan, Changning, Zhaotong, Fushun-Yongchuan, Fuling, Dingshan, and other regions [4-7]. Organic matter is the material basis for shales to generate hydrocarbon and the main reservoir space and seepage channel for shale gas. As the organic carbon's content in present shales is subject to the abundance of primitive sedimentary organic matter, it is imperative to ascertain the main factors that control the abundance [8]. Qiu and Zou [9] proposed "unconventional petroleum sedimentology" by briefly outlining its basic content. According to the theory, the sediment and enrichment of unconventional petroleum are closely related to sudden geological environment changes. They result from the sedimentary coupling of global or regional structure and multiple geological events such as sea-level rise and fall, volcanic activities, abrupt climate changes, oxygen deficit in waterbodies, and biological extinction and prosperity. Qiu et al. (2020) [9] also underlined the fluid flow's influence in the deep crust on the sedimentary organic matter's enrichment.

A series of studies have been carried out on the relationship between the deep crustal fluid activity and the accumulation of sedimentary organic matter. From the angles of paleoocean redox environment and paleoproductivity, the research by Shu et al. (2017) shows that periodical volcanic activity is the leading cause of changes in the redox environment during a sedimentary period of the upper Ordovician Wufeng-lower Silurian Longmaxi Formation. According to the research, moderate volcanic activity favors the enrichment of organic matter and biogenic siliceous minerals, promoting the formation of high-quality shales [10]. Liu et al. [11] argue that the eruption of deep fluids delivers large amounts of $\mathrm{CO}_{2}$ to the atmosphere and ocean. Then, the $\mathrm{CO}_{2}$ combines with $\mathrm{Ca}^{2+}$ and $\mathrm{Mg}^{2+}$ plasma in the water column to form carbonates, which increases the salinity of the water column and promotes water stratification and seawater circulation quiescence. As a result, favorable water dynamics and redox state for organic matter enrichment in the marine environment came into being. Besides, large quantities of reducing gases, such as $\mathrm{H}_{2} \mathrm{~S}$ and $\mathrm{CO}$, transported to the atmosphere and oceans by magmatic and hydrothermal activities can also contribute to the formation of a waterreducing environment [11]. Wang et al. (2018) [12] conclude that the thick bentonite layer, formed in the Early Silurian due to intense volcanic activity, is an important symbol for foreland basin folding and sedimentary rate increasing. Besides, it has a profound controlling influence on the formation and distribution of Wufeng-Longmaxi Formation's high-quality shale.

In recent years, the large-scale exploration of shale gas has provided more data for studying the influencing mechanism of deep geofluids on sedimentary organic matter enrichment. The deep fluid is an essential carrier of energy and material in the deep part of the earth. What is more, it is also the link between the internal and external factors of the basin. A large amount of heat energy and material carried by the deep fluid reacts physically and chemically with the material in the sedimentary basin, which influences the whole process of oil and gas formation and storage in the Earth's circle $[10,13,14]$. Deep geofluids originate from the Earth's crust or mantle and manifest as hydrothermal fluids or magma in different geohistorical periods or tectonic settings. Taking the lower Cambrian of well JXY1 in the lower Yangtze area in Southern China as the study object, this paper identifies the influencing mechanism of hydrothermal fluids on sedimentary organic matter enrichment. Also, it identifies the influencing mechanism of volcanic activities on sedimentary organic matter enrichment by taking the upper Ordovician-lower Silurian of well JSBY1 in the upper Yangtze area as the study object. Furthermore, it summarizes the influencing mode of the deep geofluids on sedimentary organic matter enrichment.

\section{Geological Settings}

\subsection{Sedimentary and Stratum Characteristics}

2.1.1. Lower Cambrian. According to previous studies [15, 16], the Yangtze Plate was divided from northwest to southeast into ancient land, shallow shelf, deep shelf, continental slope, and ocean basin in the lower Cambrian. Correspondingly, the Cathaysian Plate was divided along the same direction into the ocean basin, continental slope, deep shelf, shallow shelf, and ancient land, as shown in Figure 1(a). The two plates converge in an ocean, where the water body is deepest, and gradually become shallower towards the ancient land on both sides. A set of strata widely deposited in the two plates in the lower Cambrian are called the Wangyinpu Formation in the lower Yangtze area. It is a set of black-dark gray organic-rich siliceous shales deposited in the lower Cambrian and known as one of the target series of strata in China's shale gas exploration. The JXY1 well, located in the lower Yangtze area, is close to the boundary of the Yangtze Plate and Cathaysian Plate. The underlying stratum of the lower Cambrian Wangyinpu Formation is composed of the gray siliceous dolomite that shows an unconformable contact with the upper Sinian Piyuancun Formation, while its overlying stratum is composed of the gray siliceous shale that has a conformable contact with the lower Cambrian Guanyintang Formation.

2.1.2. Upper Ordovician-Lower Silurian. According to previous studies [17-19], the interior Cratonic sagging basin was formed after the upper Yangtze area was squeezed by the Cathaysian Plate in the upper Ordovician-lower Silurian. In the upper Yangtze region, the sedimentary strata in the upper Ordovician and the lower Silurian are called the Wufeng Formation and the Longmaxi Formation, respectively. This study mainly studies the stratum in the segment of the Wufeng Formation-the first member of the Longmaxi Formation, where shale has different lithologies. The lower segment is primarily the black organic-rich siliceous shale, while the upper one is the combination of dark gray shale, 


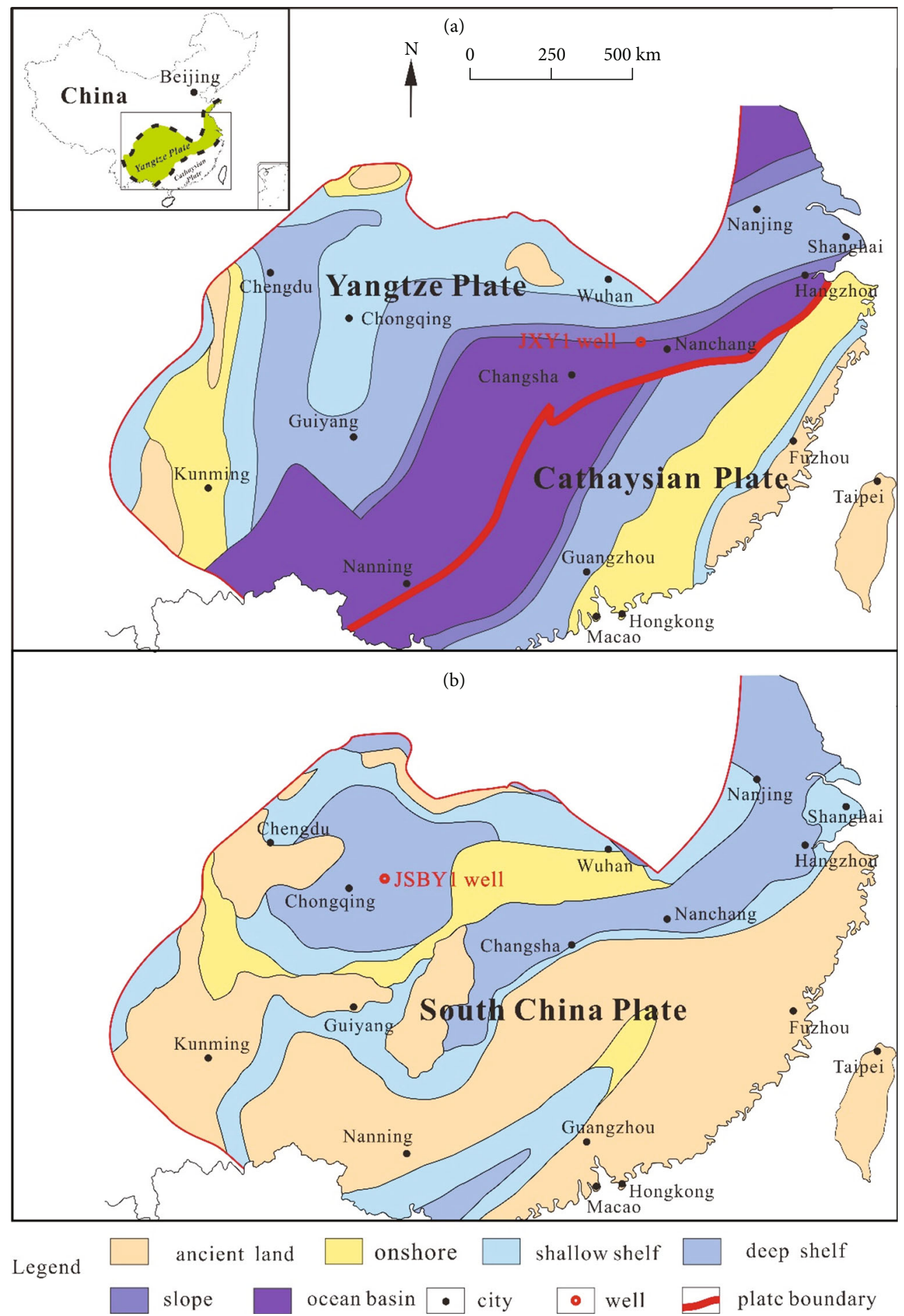

Figure 1: Sedimentary characteristics of South China in the lower Cambrian (a) and the upper Ordovician-lower Silurian (b). Modified from References [15-19].

silty shale, and siltstone. JSBY1 locates in the middle of the interior Cratonic sagging basin in the upper Yangtze area. The underlying stratum of the upper Ordovician Wufeng Formation is the gray nodular limestone showing a conformable contact with the upper Ordovician Linxiang Formation. The overlying stratum of Member 1 of the lower Silurian
Longmaxi Formation is the gray siltstone showing a conformable contact with its Member 2.

2.2. Tectonic Characteristics. As researched previously [2022], the original continental crust in South China was separated into the Yangtze Plate and Cathaysian Plate in Early 
Mesoproterozoic. In the lower Cambrian, the two plates were in a state of tension, and a large-scale transgression occurred in them resulting in the sedimentation of a set of organic-rich shales that almost covered the entire plate. Later, the water body became shallower, and the lithology developed from fine shale and silty shale into coarse clastic rocks, such as siltstone and sandstone. Due to the extrusion and collision of the Cathaysian Plate in the Ordovician, the water body continued to get shallower, thus changing the sedimentary system of clastic rocks into carbonate rocks. In the upper Ordovician-lower Silurian, the clastic rocks' sedimentary system was restored due to the large-scale transgression. As a result, a set of organic-rich shales were deposited in the deep shelf surrounded by the ancient land. In the Cambrian-Silurian, the Cathaysian Plate subducted into and collided with the Yangtze Plate. The two plates merged into the unified South China Plate at the end of the Silurian [23].

\section{Samples, Experiments, and Data Sources}

In the lower Cambrian and the upper Ordovician-lower Silurian, the Yangtze area saw widespread marine sedimentation with little facies change. In this study, the JXY1 well and JSBY1 well with complete information were taken as typical wells to analyze the mechanism of sedimentary organic matter enrichment in the lower Cambrian in the lower Yangtze area and the upper Ordovician-lower Silurian in the upper Yangtze area, respectively. Besides, the influence of deep crustal fluid on this enrichment is also studied. 28 rock core samples were selected from the JXY1 well in the lower Cambrian Wangyinpu Formation; 45 samples were chosen from the JSBY1 well in the segment of the Wufeng FormationLongmaxi Formation. The TOC content was tested by the Total Organic Carbon Analyzer (OG-2000V). Some data were collected from the literature of Guo et al. [6] and Guo et al. [24]. 84 detritus samples were selected from the JXY1 well in the lower Cambrian Wangyinpu Formation. The Xray Fluorescence Analyzer (AxiosmAX) was used for the elemental analysis of $\mathrm{Ba}, \mathrm{Al}, \mathrm{Fe}$, and $\mathrm{Mn}$.

In this paper, the log data of $\mathrm{Si}, \mathrm{Al}, \mathrm{U}$, and Th for two wells were provided by Schlumberger, and the calculating data of excess Mo $\left(\mathrm{Mo}_{\mathrm{XS}}\right)$ were collected from the works of Guo et al., which reflected the bioproductivity of the JSBY1 well in the segment of the Wufeng Formation-Longmaxi Formation. Then, the rock cores of two wells in the target series of strata were elaborated. Some data were provided by References $[25,26]$.

\section{Results and Discussion}

4.1. Bioproductivity. The Ba content is an indicator widely used to reflect the paleoocean bioproductivity [27-30]. There is a high concentration of $\mathrm{SO}_{4}{ }^{2-}$ ions reoxidized by $\mathrm{H}_{2} \mathrm{~S}$ on the surface of decayed organic matter. These ions will react with the $\mathrm{Ba}^{2+}$ in seawater to form $\mathrm{BaSO}_{4}$ and result in sedimentation. Therefore, the area with a higher bioproductivity also has a higher content of $\mathrm{BaSO}_{4}[31,32]$.

The trace elements in rocks are composed of terrigenous input constituents and authigenic ones. Only the latter can reflect the characteristics of the paleosedimentary environment [33-35]. The Ba produced under the biological action is known as excess $\mathrm{Ba}\left(\mathrm{Ba}_{\mathrm{XS}}\right)$. Generally, the estimated content of $\mathrm{Ba}$ in terrigenous clastic is subtracted from its total content:

$$
\mathrm{Ba}_{\mathrm{XS}}=\mathrm{Ba}_{\text {sample }}-\mathrm{Al}_{\text {sample }}(\mathrm{Ba} / \mathrm{Al})_{\text {PAAS }} \text {. }
$$

In this formula, $\mathrm{Ba}_{\text {sample }}$ and $\mathrm{Al}_{\text {sample }}$ refer to the total contents of $\mathrm{Ba}$ and $\mathrm{Al}$ in tested samples, respectively. PAAS represents the standard Australian shale. $(\mathrm{Ba} / \mathrm{Al})_{\mathrm{PAAS}}$ is 0.0077 , namely, the ratio of the two elements. The $\mathrm{Ba}_{\mathrm{Xs}}$ of the JXY1 well in the lower Cambrian Wangyinpu Formation is calculated and shown in Figure 2.

In an oxygen-lean-anaerobic environment, the sulfate ions in $\mathrm{BaSO}_{4}$ will be reduced by thiobacilli. Thus, $\mathrm{BaSO}_{4}$ is dissolved significantly, with some biological Ba lost [36]. As shown in Figure 2, during the sedimentary period, despite the evident dissolution of $\mathrm{BaSO}_{4}$ caused by the high reducibility in the lower Cambrian Wangyinpu Formation, the bottom and middle-upper parts still have a higher content of $\mathrm{BaSO}_{4}$.

4.2. Redox Environment. Shale's sedimentary environment is often judged by elemental geochemical characteristics. Based on the analysis of whole-rock samples, Jones et al. [37] propose that the U/Th value can reflect sedimentation's redox conditions. In general, it is an anaerobic environment when $\mathrm{U} / \mathrm{Th}>1.25$. It is an oxygen deficiency environment when $\mathrm{U} / \mathrm{Th}=0.75-1.25$. It is an oxidizing environment when $\mathrm{U} /$ Th $<0.75$. Figure 2 shows that this value is generally high, ranging from 2 to 16 , in the JXY1 well during the sedimentary period in the lower Cambrian Wangyinpu Formation. This means that the water body is of high reducibility. Thereinto, the value of this redox index is higher than 8 in the bottom and middle-upper part of the Wangyinpu Formation, showing the highest reducibility.

\subsection{Analysis of Hydrothermal Activities and Their Effect on Sedimentary Organic Matter Enrichment}

4.3.1. Analysis of Hydrothermal Activities. This study introduces the concept of excess siliceous mineral content $\left(\mathrm{Si}_{\mathrm{ex}}\right)$ to analyze the mechanism of sedimentary organic matter enrichment. The silicon sources include the terrigenous clastic sedimentation under normal circumstances, as well as the hydrothermal and biogenic activities under exceptional circumstances [38-42]. $\mathrm{Si}_{\mathrm{ex}}$ refers to the siliceous mineral that is not from the terrigenous clastic sedimentation. Its content can be calculated by the following formula:

$$
\mathrm{Si}_{\mathrm{ex}}=\mathrm{Si}_{\mathrm{s}}-\left[(\mathrm{Si} / \mathrm{Al})_{\mathrm{bg}} \times \mathrm{Al}_{\mathrm{s}}\right] \text {. }
$$

Thereinto, $\mathrm{Si}_{\mathrm{s}}$ and $\mathrm{Al}_{\mathrm{s}}$ refer to the contents of silicon and aluminum in samples, respectively. The value of $(\mathrm{Si} / \mathrm{Al})_{\mathrm{bg}}$ is 3.11, which is the average content in the shale [43].

This formula is used to calculate the content of $\mathrm{Si}_{\mathrm{ex}}$ in the JXY1 well in the lower Cambrian Wangyinpu Formation. According to the results shown in Figure $3, \mathrm{Si}_{\mathrm{ex}}$ exists in most 


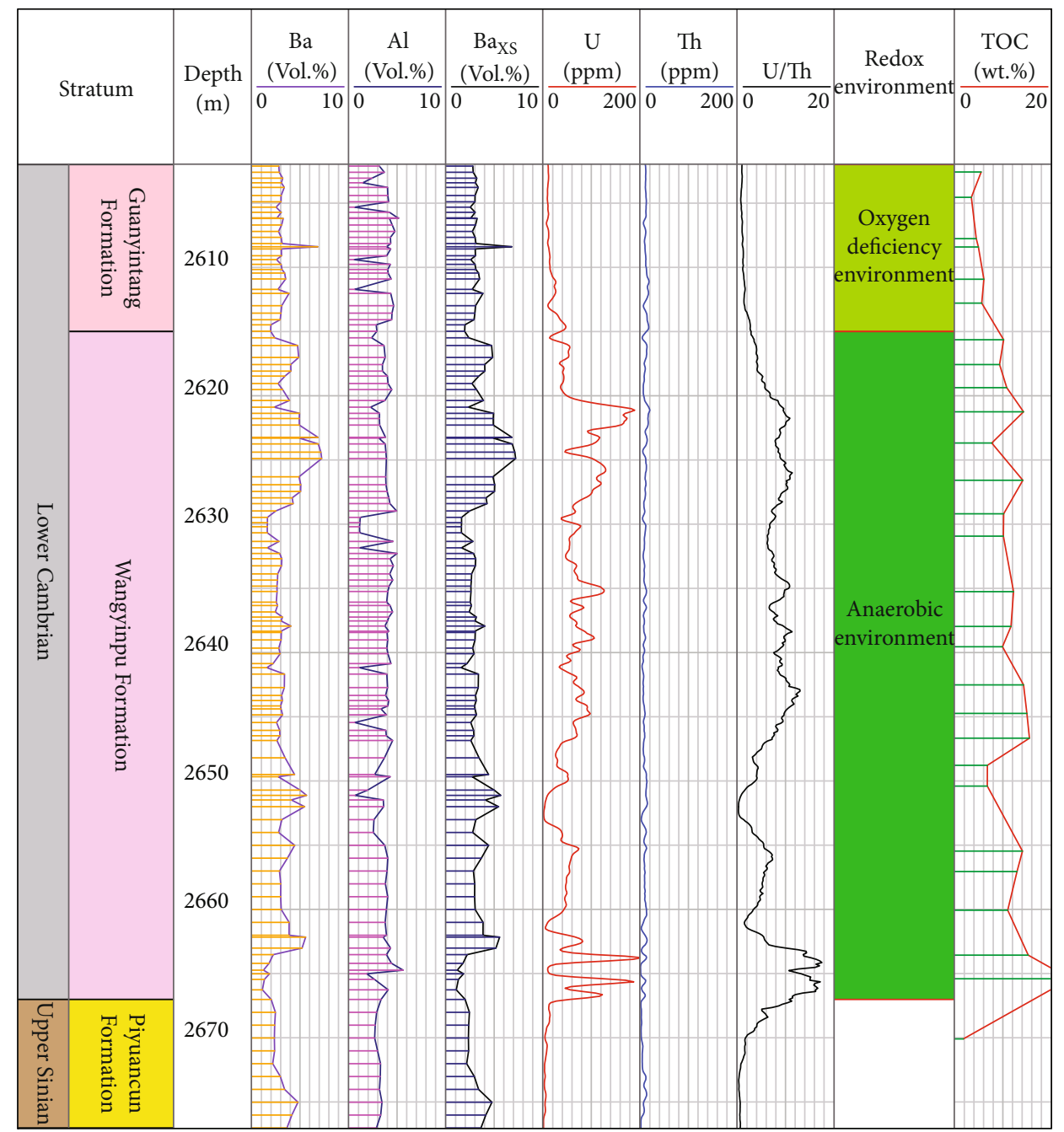

FIGURE 2: Bioproductivity $\left(\mathrm{Ba}_{\mathrm{XS}}\right)$, redox environment, and TOC content of JXY1 well in the lower Cambrian Wangyinpu Formation in the Yangtze Area (see Figure 1 for the well location).

segments of the Wangyinpu Formation. The content is 20\%$30 \%$ in half of them, while some show the value of $30 \%-40 \%$ and even of $40 \%-50 \%$.

Wedepohl, Adachi et al., and Yamamoto [44-46] suggest using the Al-Fe-Mn triangular graph to determine if the siliceous mineral is generated by hydrothermal activity or biogenic activity. In this paper, the test values of $\mathrm{Al}, \mathrm{Fe}$, and $\mathrm{Mn}$ in the segment with $\mathrm{Si}_{\mathrm{ex}}$ in the JXY1 well in the lower Cambrian Wangyinpu Formation are cast onto the graph, as shown in Figure 4. It is found that these values are distributed in the hydrothermal origin area, which indicates that $\mathrm{Si}_{\mathrm{ex}}$ is generated by hydrothermal activities.

\subsubsection{Effect of the Intensity of Hydrothermal Activities on} Sedimentary Organic Matter Enrichment. It is generally believed that hydrothermal activities relate closely to the redox environment and bioproductivity. Sun et al. and Zhang et al. [47-49] found that the seawater permeates into the deep crust through rock fractures or fractured tectonic zones and exchanges the chemical components with crustal rocks. The permeating seawater will rise and erupt from the seafloor in the form of a submarine hot spring after being heated by underground magma chambers or uncooled basalts. An anaerobic environment will be formed after the hydrothermal fluid flows into the seafloor, which contributes to the storage of organic matter.

Halbach et al. [50] analyzed the hydrothermal activity area in Fiji Basin and found that the number and activity intensity of organisms that are closer to this area will increase in the water body. The order of magnitude in this area is 1-3 higher than that on the ordinary ocean surface. McKibben et al. and Korzhinsky et al. [51, 52] believe that the hydrothermal fluid erupted is different from the ordinary seawater in the trace element composition and the contents of most metallic elements, such as $\mathrm{Fe}, \mathrm{Mn}, \mathrm{Cu}, \mathrm{Pb}, \mathrm{Zn}, \mathrm{Hg}, \mathrm{Ni}$, and Co. It carries many elements that are rare in the crustal surface. These dissolved elements contain the nutritive salts that are essential for a large number of marine organisms, which can improve the bioproductivity. Organisms will fall into the seafloor after their death, known as the "marine snow," which provides abundant substances for the organic matter enrichment of source rocks. 


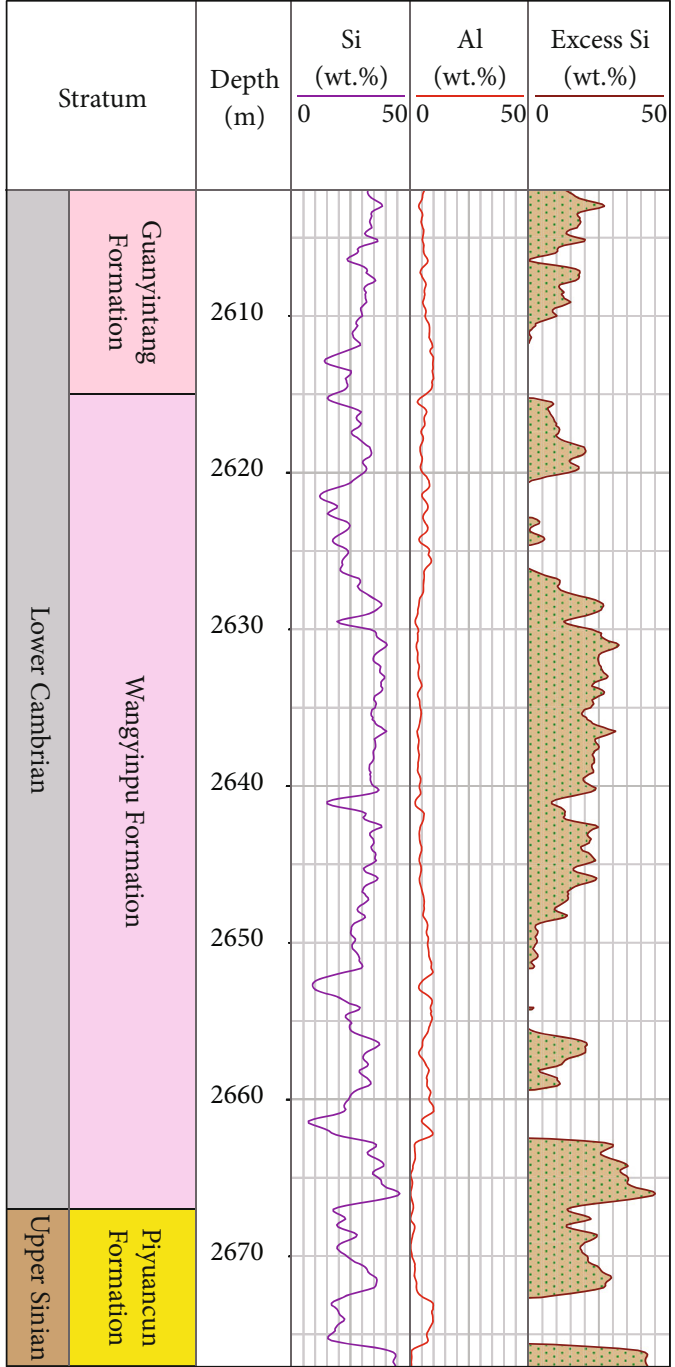

FIgURE 3: Calculation and analysis of $\mathrm{Si}_{\text {ex }}$ in the JXY1 well in the lower Cambrian Wangyinpu Formation in the Yangtze area (see Figure 1 for the well location).

The data of the JXY1 well verify the above discussion. According to Figures 2 and 3, hydrothermal activities frequently occur in the JXY1 well during the sedimentary period in the lower Cambrian Wangyinpu Formation. In most segments, the content of $\mathrm{Si}_{\mathrm{ex}}$ is $20 \%-50 \%$, and the value of $\mathrm{U} / \mathrm{Th}$ is also high, reaching 2-16. Thereinto, the activities are intense in the bottom and middle-upper part, where the U/Th exceeds 8 , with the highest reducibility.

$\mathrm{Ba}_{\mathrm{XS}}$, the bioproductivity index, shows the same trend. During the sedimentary period, the hydrothermal activities were frequent in the bottom and middle-upper part of the Wangyinpu Formation, which resulted in a higher content of $\mathrm{Ba}_{\mathrm{Xs}}$. However, the content reduced significantly in the top and middle-lower part because these activities decreased or even disappeared.

The frequent hydrothermal activities during the sedimentary period in the bottom and middle-upper part of the Wangyinpu Formation resulted in a higher bioproductivity and anoxic-reducing water. Thus, the TOC content is as high as $10 \%-20 \%$. However, these activities will decrease or even cease in the top and middle-lower part, with TOC content falling below $8 \%$ (Figure 2).

\subsection{The Influence of Volcanic Activities on the Enrichment Mechanism of Organic Matter}

4.4.1. Bioproductivity. The Mo content is widely used in paleoceanography bioproductivity evaluation [53-57]. The content may come from land-based and biological activities. Among them, Mo produced via biological effect is called $\mathrm{Mo}_{\mathrm{XS}}$, whose statistics are from Guo et al. [25]. Figure 5 shows that as the bioproductivity index of $\mathrm{Mo}_{\mathrm{xs}}$ decreases with the rise of heights in the Longmaxi Formation, it is the highest at the bottom and the lowest on the top.

4.4.2. Redox Environment. In this part, the U/Th index is also used to determine the redox environment in the upper Ordovician Wufeng-lower Silurian Longmaxi Formation of the well JSBY1. Figure 5 shows the U/Th of the lower Silurian Longmaxi Formation. It can be seen that, in the Longmaxi Formation, the U/Th value is the largest at the bottom, ranging from 1.25 to 3 . As the value decreases with height rise, it ranges from 0.75 to 1.25 in the middle and lower than 0.75 in the upper part. The observation means that the sedimentary condition gradually transformed from the oxygen-deficient to oxygen-lean one and ended up in the oxidizing environment.

\subsubsection{Analysis of Volcanic Activities and Its Influence on the Enrichment of Sedimentary Organic Matter}

(1) Analysis of Volcanic Activities. According to previous studies, the siliceous shale in Member 1 of the WufengLongmaxi Formation is of biogenic and continental clastic origins, without any siliceous mineral of hydrothermal origin $[25,57]$. Based on the detailed description of rock cores, there is bentonite in Wufeng Formation, and Longmaxi Formation Bentonite is the product of tuffaceous matters' sediment and alteration in the marine environment after the volcanic eruption. Therefore, the frequency of bentonite growth can directly reflect the volcanic eruption intensity [58-60]. The analyses of Figure 5 show that the Wufeng-Longmaxi Formation can be divided into three segments according to the frequency. In the bottom segment, the volcanic eruption was frequent because the bentonite was densely developed. In the middle, less bentonite proved that the volcanic eruption weakened. No bentonite was found in the upper segment, indicating no volcanic eruption.

(2) Volcanic Activities' Influence on the Enrichment of Sedimentary Organic Matter. The volcanic activity is the main reason for differences in the redox environment and bioproductivity in the three parts of the Wufeng-Longmaxi Formation. In the Early Silurian, the Yangtze Plate and the Cathaysian Plate collided, and the ancient lands connecting the two plates were squeezed into paleouplifts. Volcanic activities often occurred in these areas, such as paleouplifts in Centre Sichuan areas, Centre Guizhou, and Xuefeng Mountain. During the sedimentary period in the Longmaxi 


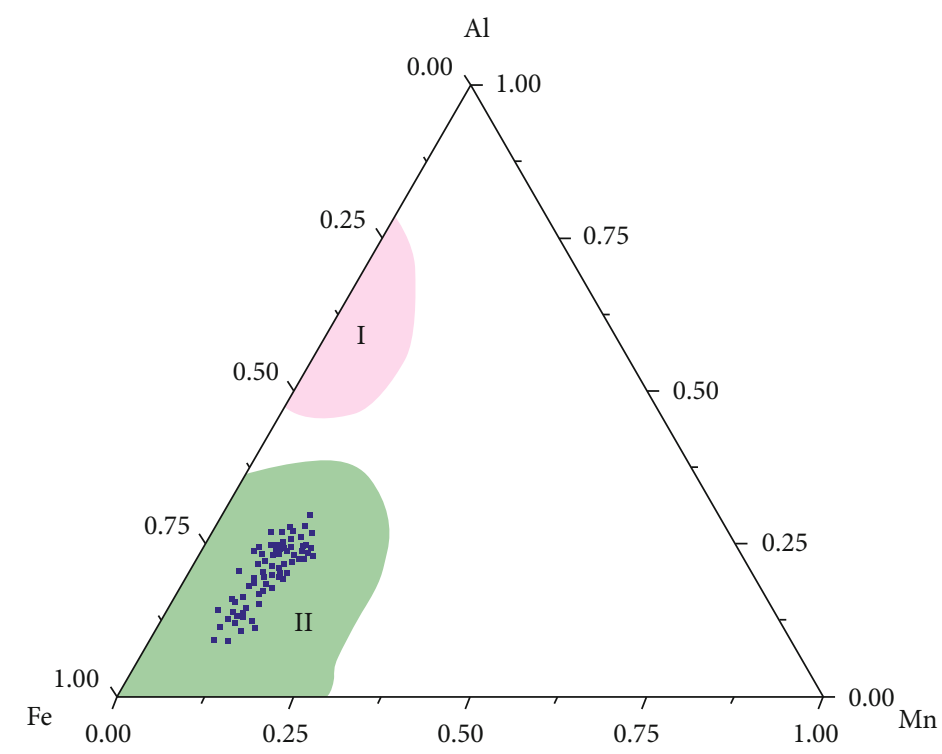

FIgURE 4: The Al-Fe-Mn triangular graph is used to analyze the siliceous mineral source in the segment with $\mathrm{Si}_{\text {ex }}$ in the XY1 well in the lower Cambrian Wangyinpu Formation. It is found that $\mathrm{Si}_{\mathrm{ex}}$ is from hydrothermal activity origin. The base map is provided by References [44-46] (see Figure 1 for the well location). I: bioorigin; II: hydrothermal origin.

Formation, the frequency and intensity were high. Large amounts of volcanic ashes and gases erupted sheltered the sunlight, causing the atmospheric environment to change dramatically and increase the waterbody's bottom's reducibility [61-63]. After falling on the waterbody's surface, volcanic ashes produced may provide planktons with nutritious minerals like $\mathrm{Fe}, \mathrm{P}, \mathrm{Mo}$, and $\mathrm{Zn}$ after hydrolytic action, which is favorable to the increase of bioproductivity $[29,56,64-67]$.

Statistics of well JSBY1 also proves the correctness of the statement above. As shown in Figure 5, considering the intense collision and squeezing between the Yangtze Plate and the Cathaysian Plate in the Early Silurian, volcanic activities were the most frequent at the bottom in Longmaxi Formation during the sedimentary period, which leads to the maximum of $\mathrm{U} / \mathrm{Th}$, the index characterizing redox environment, at about 3. During the sedimentary period, there were fewer or no volcanic activities in the middle part of Longmaxi Formation. Correspondingly, the U/Th value changes from $1.25 \sim 3$ to $0.75 \sim 1.25$ and even less with the rise of height. The value change proved that the redox environment had changed from an oxygen deficiency environment and ended up in the oxidizing condition.

This is also the case of bioproductivity index $\mathrm{Mo}_{\mathrm{xs}}$ : According to volcanic activities' activeness, in the sedimentary period of the Longmaxi Formation, the bioproductivity was the highest at the bottom while it plummeted in the middle and on the top with weakened volcanic activities.

Active volcanic activities in the lower Longmaxi Formation during the sedimentary period led to relatively high bioproductivity and anoxic-reducing water, enabling the current TOC of the lower Longmaxi Formation to be $4 \% \sim 5 \%$.
4.5. Mechanism of Deep Geofluids' Influence on the Enrichment of Sedimentary Organic Matter. Based on the above analyses, deep geofluids can be observed in the form of hydrothermal and volcanic activities that control the bioproductivity of the waterbody's surface and redox environment at the bottom and further affect the sedimentary organic matter.

As shown in Figure 6(a), in Early Cambrian, ancient China's south sea separated the Yangtze Plate and the Cathaysian Plate. During this time, large-scale transgression took place in the sedimentary period of the Wangyinpu Formation. With the widening of oceanic crusts, the pull-apart structure was intense at plates' boundaries, thus forming fractures. Besides, substances in the deep crust flowed up and were brought out by the seawater, thus bringing forth mineral-rich hydrothermal fluids that would be carried into deep water continental by the upwelling current. On the one hand, it joined the surface water with nutritive salts, promoting planktons' propagation and growth and bioproductivity. On the other hand, the fluids formed a reducible environment at the waterbody's bottom, which helped preserve the organic matter in primitive sediment. With clay minerals, silicon detritus, and biological organic matter on the surface water, the lower Cambrian shales of Wangyinpu came into being. The shales were high in silicon of hydrothermal content and TOC.

As shown in Figure 6(b), during the sedimentary period of the lower upper Ordovician Wufeng Formation and the lower Silurian Longmaxi Formation, as the Yangtze Plate and the Cathaysian Plate collided, volcanic activities had been active on ancient lands surrounded by deep water continental shelves in the upper Yangtze region. During the process, a large number of volcanic ashes were formed with nutritious elements, which promoted planktons' propagation and growth and the bioproductivity of the waterbody's 


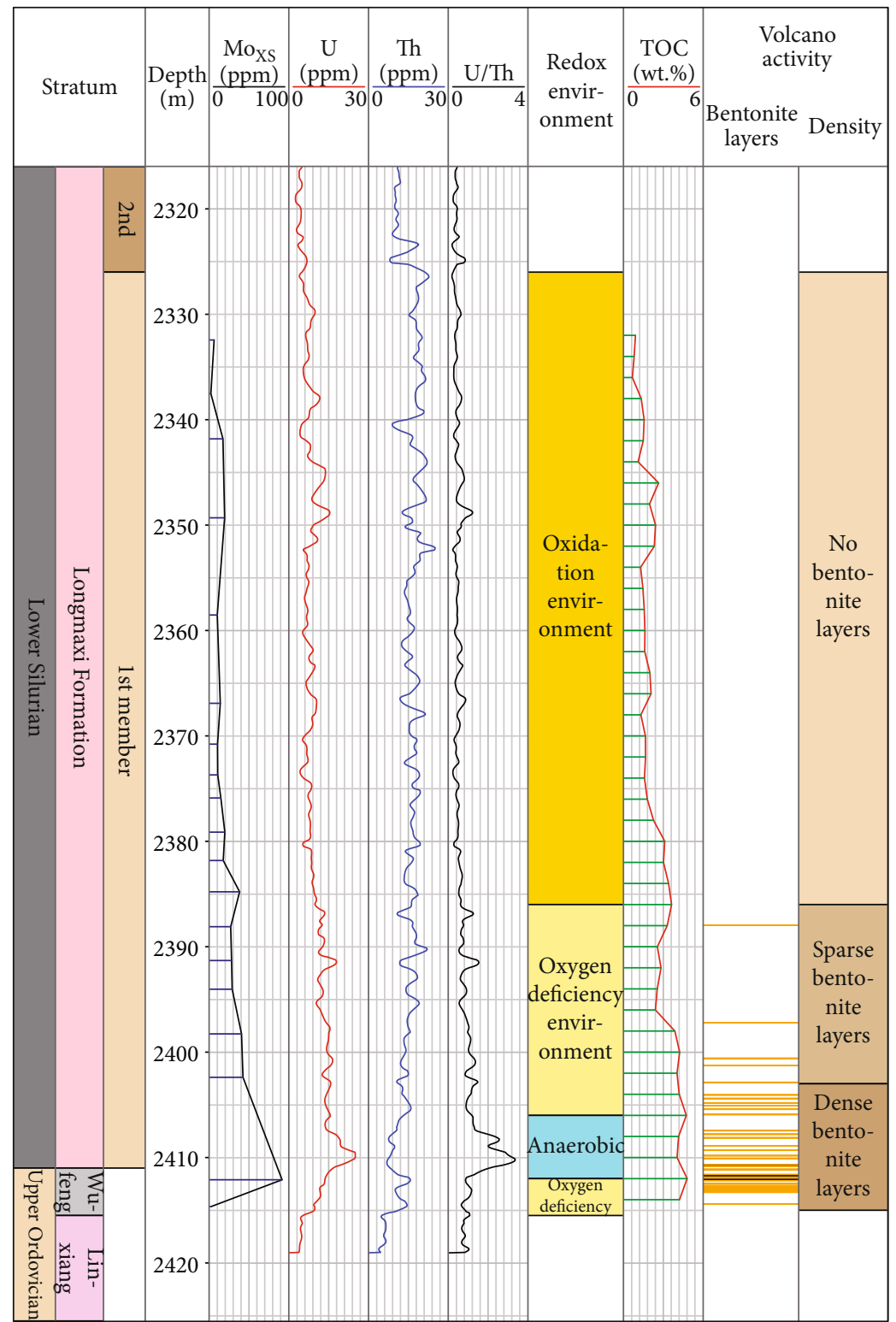

FIgUre 5: Column of $\mathrm{Mo}_{\mathrm{XS}}$, redox environment, TOC content, and growth layer of bentonite in the lower upper Ordovician Wufeng Formation and lower Silurian Longmaxi Formation in the well JSBY1 of the upper Yangtze region (see Figure 1 for the well location).

surface. Active volcanic activities might lead to climate change, increasing the reducibility of the waterbody's bottom, which was beneficial to preserve the organic matter from upper layers and the enrichment of the sedimentary organic matter.

During the upper sedimentary period in the lower Silurian Longmaxi Formation, as the collision and tension weakened, volcanic activities gradually disappeared, resulting in less volcanic ashes. It means that there was less nutrition for planktons, leading to the decrease of bioproductivity of the waterbody's surface and the reducibility of the waterbody's bottom. Some organic matter from the upper layers was broken, which hindered the enrichment of sedimentary organic matter.

\section{Conclusions}

This paper sets its research target strata as the lower Cambrian Wangyinpu Formation, the upper Ordovician Wufeng Formation, and the lower Silurian Longmaxi Formation of the Yangtze region marine shales. The objects are the drilled well JXY1of lower Cambrian and that of the upper Ordovician-lower Silurian. Based on statistics like a detailed description of rock cores, element analysis, TOC content analysis, and data calculation, the paper analyzes the mechanism of the enrichment of the sedimentary organic matter in the Yangtze region during the Late Ordovician-Early Silurian. The conclusions are as follows: 

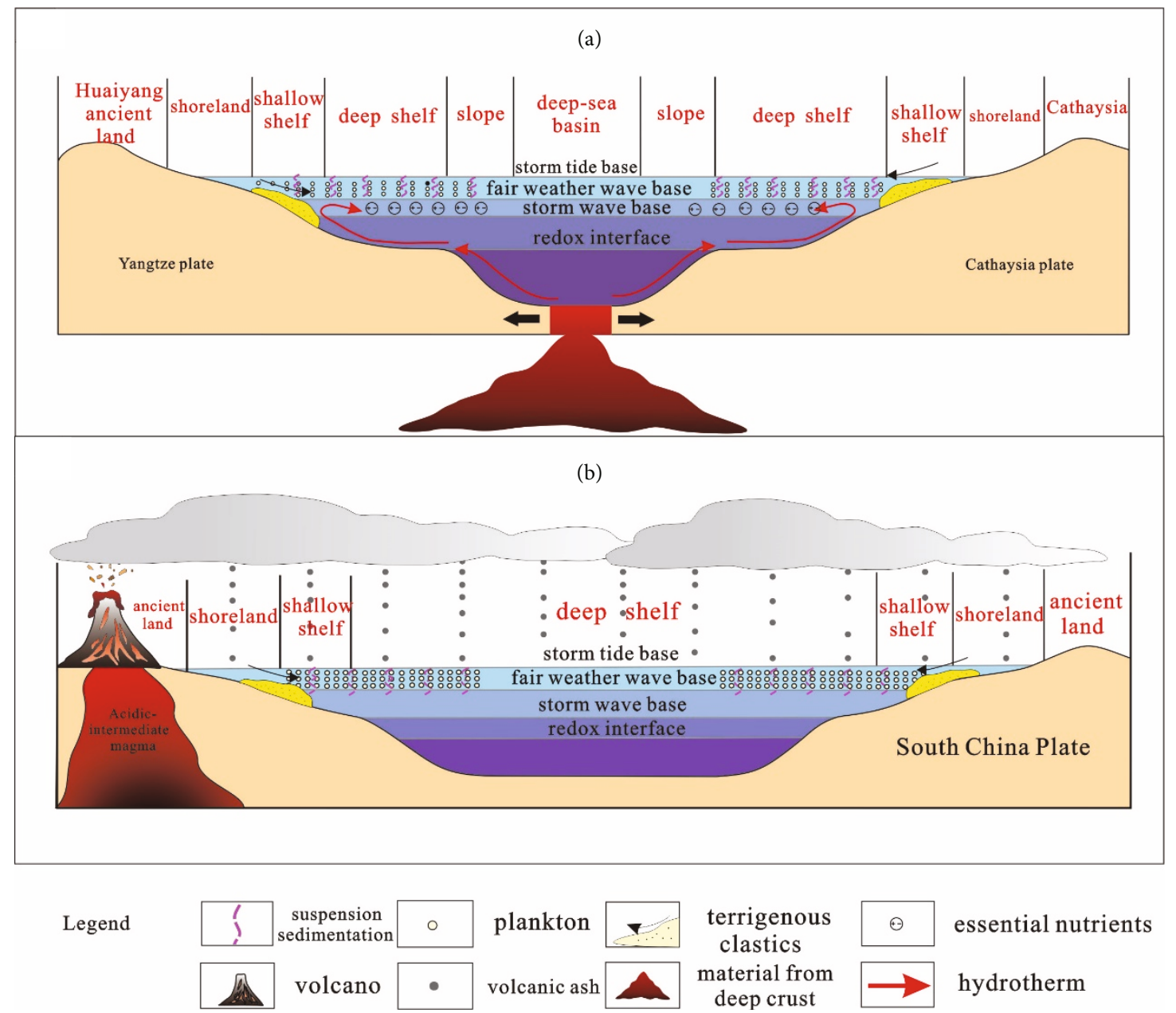

FIGURE 6: Mechanism of deep geofluids' influence on the enrichment of sedimentary organic matter. In the south of China in Early Cambrian, deep geofluids in the convergence of the Yangtze Plate and the Cathaysian were presented through hydrothermal activities, affecting the bioproductivity on the waterbody's surface and the reducibility at the waterbody's bottom (a). In Late Ordovician-Early Silurian in the same area, deep geofluids were presented by volcanic activities, affecting the bioproductivity of the waterbody's surface and the reducibility of the waterbody's bottom (b).

(1) Deep geofluids could be presented through hydrothermal and volcanic activities in different geologic conditions and tectonic settings. The fluids affected the enrichment of the sedimentary organic matter via controlling the nutrition on the waterbody's surface, the reducibility of the waterbody's bottom, and climate change

(2) There was abundant silicon of hydrothermal in lower Cambrian shales in the lower Yangtze region. Its content reflected the activeness of hydrothermal activities. At the bottom and middle-upper parts of the lower Cambrian Wangyinpu Formation, hydrothermal activities were active during the sedimentary period, increasing the bioproductivity on the waterbody's surface and the reducibility at the waterbody's bottom. In this way, plenty of sedimentary organic matter had been well preserved. In the bottom and middle-upper part of Wangyinpu Formation, with the weakening or ceasing of hydrothermal activities, the bioproductivity on the waterbody's surface decreased along with the reducibility of the waterbody's bottom. Thus, the sedimentary organic matter was destroyed due to oxidation

(3) During the sedimentary period, frequent volcanic activities in the lower upper Ordovician Wufeng Formation and lower Silurian Longmaxi Formation in the upper Yangtze region increased the bioproductivity on the waterbody's surface and the reducibility at the waterbody's bottom. As a result, the organic matter deposited from the water surface well has been well preserved. However, in Longmaxi Formation, volcanic activities died down gradually then disappeared during the sedimentary period, which 
reduced the bioproductivity on the waterbody's surface. Moreover, the small amount of organic matter deposited from the water surface was destroyed due to oxidation

\section{Data Availability}

Some of the data are contained in a published source cited in the references. All the data in this article is accessible to the readers.

\section{Additional Points}

Highlights. (1) Deep geofluids' activities influence climate change and the sources of the nutrients and reducing water. (2) Lower Cambrian shales in the lower Yangtze region contain a large amount of silicon of hydrothermal origin. (3) Both hydrothermal activities and volcanic activities increased biological productivity and intensified the reducibility, thus increasing sedimentary organic matter's content.

\section{Conflicts of Interest}

The authors declare that they have no conflicts of interest.

\section{Acknowledgments}

This study was supported by the China Postdoctoral Science Foundation (No. 2019M663560); the National Natural Science Foundation of China (No. 41872166); the Science and Technology Cooperation Project of the China National Petroleum Corporation-SWPU Innovation Alliance; the Open Fund of Key Laboratory of Tectonics and Petroleum Resources, China University of Geosciences, Wuhan, Ministry of Education (No. TPR-2020-07); and the open funds from the State Key Laboratory of Shale Oil and Gas Enrichment Mechanisms and Effective Development.

\section{References}

[1] J. B. Curtis, "Fractured shale-gas systems," AAPG Bulletin, vol. 86, no. 11, pp. 1921-1938, 2002.

[2] S. L. Montgomery, D. M. Jarvie, K. A. Bowker, and R. M. Pollastro, "Mississippian barnett shale, Fort Worth Basin, northcentral Texas: gas-shale play with multi-trillion cubic foot potential," AAPG Bulletin, vol. 89, no. 2, pp. 155-175, 2005.

[3] D. Warlick, "Gas shale and CBM development in North America," Oil \& Gas Financial Journal, vol. 3, no. 11, pp. 1-5, 2006.

[4] D. Dong, Y. Wang, X. Li et al., "Breakthrough and prospect of shale gas exploration and development in China," Natural Gas Industry B, vol. 3, no. 1, pp. 12-26, 2016.

[5] T. Guo, "Key geological issues and main controls on accumulation and enrichment of Chinese shale gas," Petroleum Exploration and Development, vol. 43, no. 3, pp. 349-359, 2016.

[6] X. Guo, D. Hu, Z. Wei, Y. Li, and X. Wei, "Discovery and exploration of Fuling shale gas field," China Petroleum Exploration, vol. 21, no. 3, pp. 24-37, 2016.

[7] X. Wei, Z. Zhao, Q. Wang, Z. Liu, M. Zhou, and H. Zhang, "Comprehensive evaluation of geological conditions of the shale gas in Upper Ordovician Wufeng Formation-Lower Silu- rian Longmaxi Formation in Dingshan area, Qijiang Southeastern Sichuan," Geological Review, vol. 63, no. 1, pp. 153164, 2017.

[8] Y. Li, D. Qiao, W. Jiang, and C. Zhang, "Gas content of gasbearing shale and its geological evaluation summary," Geological Bulletin of China, vol. 30, no. 2/3, pp. 308-317, 2011.

[9] Z. Qiu and C. Zou, "Unconventional petroleum sedimentology: connotation and prospect," Acta Sedimentologica Sinica, vol. 38, no. 1, pp. 1-29, 2020.

[10] S. Jiang, L. Chen, Y. Wu, Z. Jiang, and E. McKenna, "Hybrid plays of Upper Triassic Chang7 lacustrine source rock interval of Yanchang Formation, Ordos Basin, China," Journal of Petroleum Science and Engineering, vol. 159, pp. 182-196, 2017.

[11] J. Liu, Q. Liu, D. Zhu et al., "The role of deep fluid in the formation of organic rich souce rocks," Natural Gas Geoscience, vol. 29, no. 2, pp. 168-177, 2018.

[12] Y. Wang, X. Li, B. Chen et al., "Distribution characteristics and geological significance of the thickest Aeronian bentonite bed in middle-upper Yangtze region," Natural Gas Geoscience, vol. 29, no. 1, pp. 42-54, 2018.

[13] J. Peng, H. Zhang, and X. Lin, "Study on characteristics and genesis of botryoidal dolostone of the upper Sinian Dengying Formation: a case study from Hanyuan region, Sichuan China," Carbonates and Evaporites, vol. 33, no. 2, pp. 285299, 2018.

[14] C. Xin, L. Chen, X. Guo, and C. Wang, "Geochemical characteristics of shale gas in the Silurian Longmaxi Formation, Jiaoshiba area, Southeast Sichuan Basin, China," Energy \& Fuels, vol. 33, no. 9, pp. 8045-8054, 2019.

[15] M. Zhu, J. Zhang, M. Steiner, A. Yang, G. Li, and B. Erdtmann, "Sinian-Cambrian stratigraphic framework for shallow-to deep-water environments of the Yangtze platform: an integrated approach," Progress in Natural Science, vol. 13, no. 12, pp. 951-960, 2003.

[16] M.-Y. Zhu, L. E. Babcock, and S.-C. Peng, "Advances in Cambrian stratigraphy and paleontology: integrating correlation techniques, paleobiology, taphonomy and paleoenvironmental reconstruction," Palaeoworld, vol. 15, no. 3-4, pp. 217-222, 2006.

[17] Y. Wang, D. Dong, X. Li, J. Huang, S. Wang, and W. Wu, "Stratigraphic sequence and sedimentary characteristics of lower Silurian Longmaxi Formation in the Sichuan Basin and its peripheral areas," Natural Gas Industry B, vol. 35, no. 3, pp. 12-21, 2015.

[18] C. Zou, D. Dong, Y. Wang et al., "Shale gas in China: characteristics, challenges and prospects (I)," Petroleum Exploration and Development, vol. 42, no. 6, pp. 689-701, 2015.

[19] C. Mou, X. Wang, Q. Wang et al., "Relationship between sedimentary facies and shale gas geological conditions of the lower Silurian Longmaxi Formation in southern Sichuan Basin and its adjacent areas," Journal of Palaeogeography, vol. 18, no. 3, pp. 457-472, 2016.

[20] Z.-X. Li, L. Zhang, and C. M. A. Powell, "South China in Rodinia: part of the missing link between Australia-east Antarctica and Laurentia," Geology, vol. 23, no. 5, pp. 407-410, 1995.

[21] Z.-X. Li, X.-h. Li, H. Zhou, and P. D. Kinny, "Grenvillian continental collision in South China: new SHRIMP U-Pb zircon results and implications for the configuration of Rodinia," Geology, vol. 30, no. 2, pp. 163-166, 2002.

[22] J. Wang and Z. Li, "History of Neoproterozoic rift basins in South China: implications for Rodinia break-up," Precambrian Research, vol. 122, no. 1-4, pp. 141-158, 2003. 
[23] L. Mei, D. Deng, C. Shen, and Z. Liu, "Tectonic dynamics and marine hydrocarbon accumulation of Jiangnan-Xuefeng uplift," Geological Science and Technology Information, vol. 31, no. 5, pp. 85-93, 2012.

[24] X. Guo, Y. Li, B. Tenger et al., "Hydrocarbon generation and storage mechanisms of deepwater shelf shales of Ordovician Wufeng Formation Silurian Longmaxi Formation in Sichuan basin, China," Petroleum Exploration and Development, vol. 47, no. 1, pp. 204-213, 2020.

[25] X. Guo, D. Hu, Y. Li, Z. Wei, X. Wei, and Z. Liu, "Geological factors controlling shale gas enrichment and high production in Fuling shale gas field," Petroleum Exploration and Development, vol. 44, no. 4, pp. 513-523, 2017.

[26] X. Liu, Z. Jiang, K. Zhang et al., "Mechanism analysis of organic matter enrichment of upper Ordovician-lower Silurian shale in the upper Yangtze area: taking Jiaoye-1 well in the Jiaoshiba block as an example," Geofluids, vol. 2019, Article ID 5806023, 13 pages, 2019.

[27] W. Ji, Y. Song, Z. Rui, M. Meng, and H. Huang, "Pore characterization of isolated organic matter from high matured gas shale reservoir," International Journal of Coal Geology, vol. 174, pp. 31-40, 2017.

[28] W. Ji, F. Hao, H.-M. Schulz, Y. Song, and J. Tian, "The architecture of organic matter and its pores in highly mature gas shales of the lower Silurian Longmaxi Formation in the upper Yangtze platform, South China," AAPG Bulletin, vol. 103, no. 12, pp. 2909-2942, 2019.

[29] X. Zhao, K. Qi, L. Liu, C. Gong, and W. D. Mccaffrey, "Development of a partially-avulsed submarine channel on the Niger Delta continental slope: architecture and controlling factors," Marine and Petroleum Geology, vol. 95, pp. 30-49, 2018.

[30] K. Zhang, C. Jia, Y. Song et al., "Analysis of lower Cambrian shale gas composition, source and accumulation pattern in different tectonic backgrounds: a case study of Weiyuan block in the upper Yangtze region and Xiuwu Basin in the lower Yangtze region," Fuel, vol. 263, p. 115978, 2020.

[31] K. Zhang, Z. Li, S. Jiang et al., "Comparative analysis of the siliceous source and organic matter enrichment mechanism of the upper Ordovician-lower Silurian shale in the upperlower Yangtze area," Minerals, vol. 8, no. 7, p. 283, 2018.

[32] K. Zhang, Z. Jiang, L. Yin et al., "Controlling functions of hydrothermal activity to shale gas content-taking lower Cambrian in Xiuwu Basin as an example," Marine and Petroleum Geology, vol. 85, pp. 177-193, 2017.

[33] K. Zhang, Y. Song, S. Jiang et al., "Accumulation mechanism of marine shale gas reservoir in anticlines: a case study of the southern Sichuan Basin and Xiuwu Basin in the Yangtze region," Geofluids, vol. 2019, Article ID 5274327, 14 pages, 2019.

[34] K. Zhang, Y. Song, S. Jiang et al., "Mechanism analysis of organic matter enrichment in different sedimentary backgrounds: a case study of the lower Cambrian and the upper Ordovician-lower Silurian, in Yangtze region," Marine and Petroleum Geology, vol. 99, pp. 488-497, 2019.

[35] J. Peng, J. Liu, Y. Wang, and J. Liu, “Origin and controlling factors of chlorite coatings-an example from the reservoir of T3x Group of the Baojie area, Sichuan Basin, China," Marine and Petroleum Geology, vol. 6, no. 4, pp. 376-382, 2009.

[36] H. Wei, "Productivity and redox proxies of palaeo-oceans: an overview of elementary geochemistry," Sedimentary Geology and Tethyan Geology, vol. 32, no. 2, pp. 76-88, 2012.
[37] B. Jones and D. A. C. Manning, "Comparison of geochemical indices used for the interpretation of palaeoredox conditions in ancient mudstones," Chemical Geology, vol. 111, no. 1-4, pp. 111-129, 1994.

[38] K. Boström, T. Kraemer, and S. Gartner, "Provenance and accumulation rates of opaline silica, $\mathrm{Al}, \mathrm{Ti}, \mathrm{Fe}, \mathrm{Mn}, \mathrm{Cu}, \mathrm{Ni}$ and Co in Pacific pelagic sediments," Chemical Geology, vol. 11, no. 2, pp. 123-148, 1973.

[39] R. W. Murray, M. R. Buchholtz ten Brink, D. C. Gerlach, G. P. Russ III, and D. L. Jones, "Rare earth, major, and trace elements in chert from the Franciscan Complex and Monterey Group, California: assessing REE sources to fine-grained marine sediments," Geochimica et Cosmochimica Acta, vol. 55, no. 7, pp. 1875-1895, 1991.

[40] J. Liu and M. Zheng, "Geochemistry of hydrothermal sedimentary silicalite," Acta Geologica Sichuan, vol. 13, no. 2, pp. 110-118, 1993.

[41] J. Yang, D. Wang, J. Mao, Z. Zhang, Z. Zhang, and Z. Wang, "The petrochemical research method for silicalite and its application to the "Jingtieshan type" iron deposits," Acta Petrologica et Mineralogical, vol. 18, no. 2, pp. 108-118, 1999.

[42] Z. Liu, B. Gao, Y. Zhang, W. Du, D. Feng, and H. Nie, “Types and distribution of the shale sedimentary facies of the lower Cambrian in upper Yangtze area, South China," Petroleum Exploration and Development, vol. 44, no. 1, pp. 20-31, 2017.

[43] H. K. Holdaway and C. J. Clayton, "Preservation of shell microstructure in silicified brachiopods from the upper cretaceous Wilmington sands of Devon," Geological Magazine, vol. 119, no. 4, pp. 371-382, 1982.

[44] K. H. Wedepohl, "Environmental influences on the chemical composition of shales and clays," Physics and Chemistry of the Earth, vol. 8, pp. 307-333, 1971.

[45] M. Adachi, K. Yamamoto, and R. Sugisaki, "Hydrothermal chert and associated siliceous rocks from the northern Pacific their geological significance as indication of ocean ridge activity," Sedimentary Geology, vol. 47, no. 1-2, pp. 125-148, 1986.

[46] K. Yamamoto, "Geochemical characteristics and depositional environments of cherts and associated rocks in the Franciscan and Shimanto Terranes," Sedimentary Geology, vol. 52, no. 12, pp. 65-108, 1987.

[47] X. Sun, J. Chen, W. Liu, S. Zhang, and D. Wang, "Hydrothermal venting on the seafloor and formation of organic-rich sediments: evidence from the Neoproterozoic Xiamaling Formation, North China," Geological Reviews, vol. 49, no. 6, pp. 588-595, 2003.

[48] X. Sun, J. Chen, J. Zheng, and W. Liu, "Geochemical characteristics of organic matter-rich sedimentary strata in lower Cambrian, Tarim Basin and its origins," Acta Sedimentologica Sinica, vol. 22, no. 3, pp. 548-552, 2004.

[49] Z. Wenzheng, Y. Hua, X. Liqin, and Y. Yihua, "Lake-bottom hydrothermal activities and their influence on high-quality source rock development: a case from Chang 7 source rocks in Ordos Basin," Petroleum Exploration and Development, vol. 37, no. 4, pp. 424-429, 2010.

[50] M. Halbach, A. Koschinsky, and P. Halbach, "Report on the discovery of gallionella ferruginea from an active hydrothermal field in the deep sea," InterRidge News, vol. 10, no. 1, pp. 18-20, 2001.

[51] M. A. McKibben, A. E. Williams, and G. E. M. Hall, "Solubility and transport of plantinum-group elements and Au in saline 
hydrothermal fluids; constraints from geothermal brine data," Economic Geology, vol. 85, no. 8, pp. 1926-1934, 1990.

[52] M. A. Korzhinsky, S. I. Tkachenko, K. I. Shmulovich, Y. A. Taran, and G. S. Steinberg, "Discovery of a pure rhenium mineral at Kudriavy volcano," Nature, vol. 369, no. 6475, pp. 5152,1994

[53] K. Zhang, Z. Jiang, X. Xie et al., "Lateral percolation and its effect on shale gas accumulation on the basis of complex tectonic background," Geofluids, vol. 2018, Article ID 5195469, 11 pages, 2018.

[54] K. Zhang, Y. Song, C. Jia et al., "Vertical sealing mechanism of shale and its roof and floor and effect on shale gas accumulation, a case study of marine shale in Sichuan basin, the upper Yangtze area," Journal of Petroleum Science and Engineering, vol. 175, pp. 743-754, 2019.

[55] K. Zhang, Y. Song, S. Jiang et al., "Shale gas accumulation mechanism in a syncline setting based on multiple geological factors: an example of southern Sichuan and the Xiuwu Basin in the Yangtze region," Fuel, vol. 241, pp. 468-476, 2019.

[56] X. Zhao, M. Li, K. Qi et al., "Development of a distinct submarine depositional system on a topographically complex Niger Delta slope," Geological Journal, vol. 55, no. 5, pp. 37323747, 2020.

[57] S. Wang, C. Zou, D. Dong, Y. Wang, J. Huang, and Z. Guo, "Biogenic silica of organic-rich shale in Sichuan Basin and its significance for shale gas," Acta Scientiarum Naturalium Universitatis Pekinensis, vol. 50, no. 3, pp. 476-486, 2014.

[58] A. Robock, "Volcanic eruptions and climate," Reviews of Geophysics, vol. 38, no. 2, pp. 191-219, 2000.

[59] S. Self, M. Widdowson, T. Thordarson, and A. E. Jay, "Volatile fluxes during flood basalt eruptions and potential effects on the global environment: a Deccan perspective," Earth and Planetary Science Letters, vol. 248, no. 1-2, pp. 518-532, 2006.

[60] P. B. Wignall, Y. Sun, D. P. G. Bond et al., "Volcanism, mass extinction, and carbon isotope fluctuations in the middle Permian of China," Science, vol. 324, no. 5931, pp. 11791182, 2009.

[61] C. Zou, Z. Qiu, S. W. Poulton et al., "Ocean euxinia and climate change "double whammy" drove the late Ordovician mass extinction," Geology, vol. 46, no. 6, pp. 535-538, 2018.

[62] K. A. Mustafa, M. A. Sephton, J. S. Watson, F. Spathopoulos, and P. Krzywiec, "Organic geochemical characteristics of black shales across the Ordovician-Silurian boundary in the Holy Cross Mountains, Central Poland," Marine and Petroleum Geology, vol. 66, pp. 1042-1055, 2015.

[63] M. H. Saberi, A. R. Rabbani, and M. Ghavidel-syooki, "Hydrocarbon potential and palynological study of the Latest Ordovician - Earliest Silurian source rock (Sarchahan Formation) in the Zagros Mountains, southern Iran," Marine and Petroleum Geology, vol. 71, pp. 12-25, 2016.

[64] B. Lu, Z. Qiu, B. Zhang, and J. Li, "Geochemical characteristics and geological significance of the bedded chert during the Ordovician and Silurian transition in the Shizhu area, Chongqing, South China," Canadian Journal of Earth Sciences, vol. 56, no. 4, pp. 419-430, 2019.

[65] H. Wei, D. Chen, J. Wang, H. Yu, and M. E. Tucker, "Organic accumulation in the lower Chihsia formation (middle Permian) of South China: constraints from pyrite morphology and multiple geochemical proxies," Palaeogeography, Palaeoclimatology, Palaeoecology, vol. 353-355, pp. 73-86, 2012.
[66] T. M. Blattmann, Z. Liu, Y. Zhang et al., "Mineralogical control on the fate of continentally derived organic matter in the ocean," Science, vol. 366, no. 6466, pp. 742-745, 2019.

[67] X. Zhao, K. Qi, M. Patacci, C. Tan, and T. Xie, "Submarine channel network evolution above an extensive masstransport complex: a 3D seismic case study from the Niger delta continental slope," Marine and Petroleum Geology, vol. 104, pp. 231-248, 2019. 